Article

\title{
Characterization of Severely Biodegraded Crude Oils Using Negative-Ion ESI Orbitrap MS, GC-NCD and GC-SCD: Insights into Heteroatomic Compounds Biodegradation
}

\author{
Xiong Cheng * and Dujie Hou
}

check for updates

Citation: Cheng, X.; Hou, D. Characterization of Severely Biodegraded Crude Oils Using Negative-Ion ESI Orbitrap MS, GC-NCD and GC-SCD: Insights into Heteroatomic Compounds Biodegradation. Energies 2021, 14, 300. https://doi.org/10.3390/ en14020300

Received: 3 December 2020 Accepted: 4 January 2021 Published: 7 January 2021

Publisher's Note: MDPI stays neutral with regard to jurisdictional clai$\mathrm{ms}$ in published maps and institutional affiliations.

\section{Copyright: $(2021$ by the authors. Li-} censee MDPI, Basel, Switzerland. This article is an open access article distributed under the terms and conditions of the Creative Commons Attribution (CC BY) license (https:// creativecommons.org/licenses/by/ $4.0 /)$.
School of Energy Resources, China University of Geosciences, Beijing 100083, China; hdj@cugb.edu.cn

* Correspondence: xcheng2015@cugb.edu.cn

\begin{abstract}
A slightly and two severely biodegraded crude oils with the same origin were analysed using negative-ion electrospray ionization Orbitrap mass spectrometry (ESI Orbitrap MS), gas chromatography-nitrogen chemiluminescence detector (GC-NCD), and GC-sulfur chemiluminescence detector (GC-SCD) to investigate the composition of heteroatomic compounds and their fate during severe biodegradation and to provide insights into biodegradation pathway of hopanes, nitrogen- and sulfur-containing compounds. Twelve heteroatomic compound classes, including $\mathrm{O}_{1}-\mathrm{O}_{5}, \mathrm{~N}_{1}, \mathrm{~N}_{2}, \mathrm{~N}_{1} \mathrm{O}_{1}-\mathrm{N}_{1} \mathrm{O}_{3}, \mathrm{~N}_{1} \mathrm{~S}_{1}$ and $\mathrm{O}_{3} \mathrm{~S}_{1}$, were detected and assigned unambiguous molecular formulae. The $\mathrm{O}_{1}$ species are likely phenols with additional naphthenic and/or aromatic rings. Carboxylic acids $\left(\mathrm{O}_{2}\right.$ species) are originated from oxidation of hydrocarbons, and the tricyclic naphthenic acids are the most resistant, followed by bicyclics. Hopanes could be biodegraded by demethylation or by unstable hopanoic acids as intermediates to yield 25-norhopanes. The $\mathrm{N}_{1}$ species are pyrrolic compounds with naphthenic and/or aromatic rings and are dominated by carbazole analogues. Carbazoles with more aromatic rings are more resistant to biodegradation. The $\mathrm{N}_{1}$ species could be converted to $\mathrm{N}_{1} \mathrm{O}_{1}$ and $\mathrm{N}_{1} \mathrm{O}_{2}$ compounds via ring-opening and hydroxylation pathways. The $\mathrm{N}_{1} \mathrm{~S}_{1}$ species contain a pyrrolic and cyclic sulfide structure, which are highly recalcitrant to biodegradation. Benzothiophenes and dibenzothiophenes might be biodegraded via the complete pathway or the sulfur-specific pathway rather than by other pathways to yield acidic oxygenated sulfur compounds.
\end{abstract}

Keywords: biodegradation; crude oil; ultra-high-resolution mass spectrometry; ESI Orbitrap MS; NSO compounds

\section{Introduction}

Biodegradation is a widespread phenomenon that alters the chemical and physical properties of crude oil in reservoirs as well as surface seeps, spills, and contamination. The effect of biodegradation on aliphatic and aromatic hydrocarbons have been well understood, such as the relative susceptibility of hydrocarbons to biodegradation [1-4] and their biodegradation pathways [5-7]. However, the effect on polar fraction is less well documented [8,9] because polar compounds are usually not amenable to traditional gas- or liquid-chromatographic and mass spectrometric analyses due to their complex and non-volatile nature $[8,10]$.

Fourier transform ion cyclotron resonance mass spectrometry (FT-ICR MS) and Orbitrap MS have high mass resolution and high mass accuracy which allow for the resolution and elemental composition assignment of thousands of NSO compounds in petroleum and other complex mixtures [11-14]. Negative- and positive-ion electrospray can selectively ionize acidic species (e.g., acids, phenols and pyrrolic nitrogen compounds) and most basic species (many of which contain pyridinic nitrogen), respectively [15-17]. The combination of ESI source and FT-ICR MS or Orbitrap MS, therefore, provide an opportunity to characterize the complex polar compounds in crude oil, oil fractions (resin and asphaltene), and coal tar. 
ESI FT-ICR MS has been used to characterize heteroatom compounds in crude oils of different geochemical origins [17-20], and to investigate the effect of thermal maturity [21,22], primary and secondary migration [23-25] and hydrothermal [26,27] on polar NSO compounds in crude oils and source rock extractions. In contrast, ESI Orbitrap MS was less applied to characterize complex compounds in petroleum [14,28-31].

Although FT-ICR MS is the most advanced mass analyzers in terms of high accuracy and resolving power with sub-ppm mass accuracy, it has disadvantages of a relatively slow acquisition rate ( $1 \mathrm{~Hz}$ with mass resolution of 100,000 at $\mathrm{m} / \mathrm{z} 4000)$, a high operational cost and expensive maintenance [31,32]. In contrast, Orbitrap MS has a faster scanning rate at $15 \mathrm{~Hz}$ with $<1 \mathrm{ppm}$ mass accuracy [32] and a lower cost [14,31], and is more suitable for characterizing relatively low molecular weight compounds [29].

Many previous studies have revealed the impact of slight to heavy biodegradation on polar NSO compounds in crude oils under field and laboratory conditions using negativeion ESI FT-ICR MS [33-37]. However, the response of polar NSO species in crude oils to very severe biodegradation and the corresponding biodegradation pathways have not been well understood. To expand our knowledge about biodegradation of heteroatomic compounds under geological conditions, a slightly and two severely biodegraded reservoir crude oils, which have been proved to be genetically related, were analysed using negativeion ESI Orbitrap MS together with GC-NCD and GC-SCD. The present study revealed the fate and compositional changes of polar NSO compounds under severe biodegradation and provided insights into the possible biodegradation pathways of hopanes and nitrogenand sulfur-containing species.

\section{Materials and Methods}

\subsection{Sample Descriptions}

Recently, a suite of genetically related crude oils from the Miaoxi Depression of the Bohai Bay Basin, China, subjected to light to very severe biodegradation, was studied by Cheng et al., analyzing the effects of biodegradation on saturated and aromatic hydrocarbons [38-40]. A subset of three crude oils from the archive were used in this study. They comprise a reference oil (PL15-1B, slightly biodegraded) and two severely biodegraded oils (PL15-1A and PL15-8C) with increasing extents of biodegradation (Table 1). Figure 1 shows the distribution of biomarkers and aromatic hydrocarbons in the crude oils. n-Alkanes were removed, and isoprenodis, tricyclic terpanes, hopanes, steranes, and aromatic hydrocarbon were found intact in the PL15-1B oil, suggesting slightly biodegradation. In the PL15-1A oil, n-alkanes and isoprenodis were removed, naphthalenes and phenanthrenes were considerably depleted, hopanes and regular steranes were significantly altered, but tricyclic terpanes were intact, suggesting severe biodegradation (level 7 based on the Peters and Moldowan biodegradation scale [3]. The PL15-8C oils was more severely biodegraded (level 8), as n-alkanes, isoprenodis, hopanes, steranes, and aromatic hydrocarbon were almost completely removed, and $\mathrm{C}_{19}-\mathrm{C}_{23}$ tricyclic terpanes were considerably altered.

Table 1. Basic information of the studied crude oils and parameters, showing the increasing biodegradation levels of the samples (adapted from [39]).

\begin{tabular}{cccccc}
\hline Sample ID & Depth $(\mathbf{m})$ & $\mathrm{D}_{\mathbf{2 9}} / \mathrm{C}_{\mathbf{3 0}} \mathbf{H}$ & $\mathrm{C}_{\mathbf{2 1}} \mathrm{TT} / \mathrm{C}_{\mathbf{2 4}} \mathrm{TT}$ & $\mathrm{C}_{\mathbf{2 3}} \mathbf{T T} / \mathrm{C}_{\mathbf{2 4}} \mathrm{TT}$ & PM Level \\
\hline PL15-1B & $1475-1478$ & - & 1.36 & 1.6 & - \\
PL15-1A & $1164-1170$ & 0.69 & 1.32 & 1.6 & 7 \\
PL15-8C & $1747-1758$ & 6.16 & 0.2 & 0.61 & 8 \\
\hline
\end{tabular}

$\mathrm{D}_{29} / \mathrm{C}_{30} \mathrm{H}: \mathrm{C}_{29}$ 25-norhopane/ $\mathrm{C}_{30} 17 \alpha(\mathrm{H})$-hopane; TT: tricyclic terpane; PM level: biodegradation level based on Peters and Moldowan [4] biodegradation scale. 


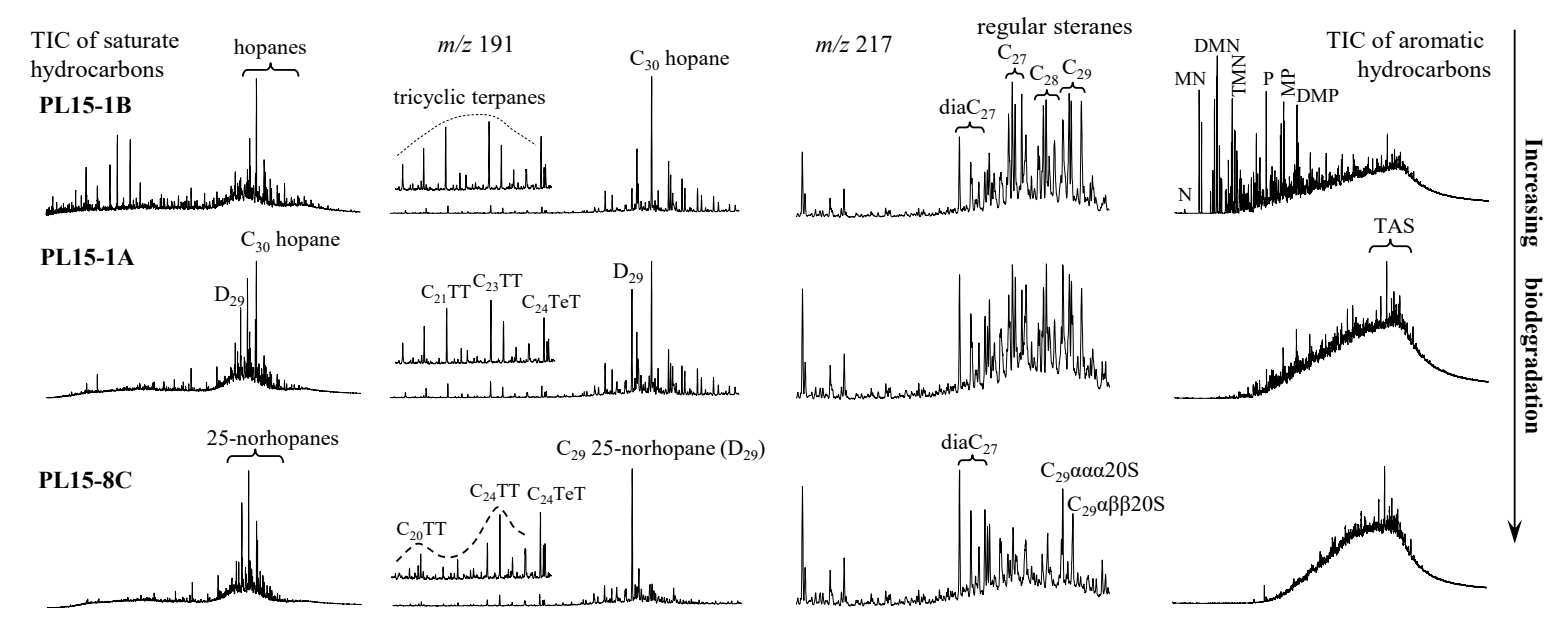

Figure 1. Total ion chromatogram (TIC) of aliphatic fractions, partial $m / z 191$ mass chromatograms for tricyclic and pentacyclic terpanes, partial $\mathrm{m} / z 217$ mass chromatograms for regular steranes and diasteranes and TIC of aromatic fractions for the studied oils showing increasing degree of biodegradation

\subsection{GC-NCD and GC-SCD}

GC-amendable nitrogen and sulfur compounds were analysed using an Agilent 7890A GC equipped with an Agilent 355 SCD detector and a 7890A GC coupled with a 255 NCD detector, respectively. A HP-5 MS fused silica capillary column $(30 \mathrm{~m} \times 0.25 \mathrm{~mm} \times 0.25 \mu \mathrm{m})$ was used to separate the compounds. The initial GC oven temperature was maintained at $50{ }^{\circ} \mathrm{C}$ (hold for $1 \mathrm{~min}$ ), and then ramped to $300{ }^{\circ} \mathrm{C}$ at a rate of $10{ }^{\circ} \mathrm{C} / \mathrm{min}$ with a final hold of $20 \mathrm{~min}$. For GC-NCD analysis, helium was used as carrier gas at a flow rate of $1.0 \mathrm{~mL} / \mathrm{min}$; hydrogen (burning gas) and oxygen (oxidant gas) flow rates were set at 48.8 and $65.7 \mathrm{~mL} / \mathrm{min}$, respectively, and the burner temperature was set at $800^{\circ} \mathrm{C}$. For GC-SCD analysis nitrogen was used as carrier gas at a flow rate of $0.8 \mathrm{~mL} / \mathrm{min}$; hydrogen and air flow rates were set at 46 and $66 \mathrm{~mL} / \mathrm{min}$, respectively, and the burner temperature was set at $800{ }^{\circ} \mathrm{C}$.

\subsection{Negative-Ion ESI Orbitrap MS and Data Processing}

Crude oils were dissolved in toluene to produce $10 \mathrm{mg} / \mathrm{mL}$ solutions, and $20 \mu \mathrm{L}$ of each solution were diluted with $1 \mathrm{~mL}$ of toluene:methanol (1:3, v:v). $20 \mu \mathrm{L}$ of ammonia water was added to enhance the ionization efficiency. These pretreated oil samples were analysed using an Orbitrap MS (Thermo Fisher Scientific, Waltham, MA, USA) equipped with an ESI source. The ESI source was operated in negative-ion mode. The conditions for data acquisition are as follows: Samples were diffused directly into the ESI ionization source at a rate of $5 \mu \mathrm{L} / \mathrm{min}$. The velocity of sheath gas and auxiliary gas were $5.0 \mathrm{Arb}$ and 2.0 Arb, respectively. The temperature of ion transport tube and vaporizer were settled at $300{ }^{\circ} \mathrm{C}$ and $200{ }^{\circ} \mathrm{C}$, respectively. The scanning mass range was from $\mathrm{m} / z 50$ to 800 .

Instrument control and data acquisition were performed using the Xcalibur software (Version 2.2; Thermo-Fisher Scientific). Mass calibration and data processing procedures have been previously documented in detail by Shi et al. [41,42]. Mass peaks with signalto-noise ratio greater than 6 were exported to a spreadsheet for elemental composition assignment using DataAnalysis software (Version 3.4; Bruker Daltonics). For a molecule formula $\mathrm{C}_{\mathrm{C}} \mathrm{H}_{\mathrm{h}} \mathrm{N}_{\mathrm{n}} \mathrm{O}_{\mathrm{o}} \mathrm{S}_{\mathrm{s}}$, the double bond equivalent (DBE) value was calculated based on the formula: $\mathrm{DBE}=\mathrm{c}-\mathrm{h} / 2+\mathrm{n} / 2+1$.

\section{Results and Discussion}

\subsection{GC-Amendable Nitrogen and Sulfur Compounds}

For crude oils, indols and carbazoles are the major nitrogen-containing compounds detected by GC-NCD, and benzothiophenes (BTs) and dibenzothiophenes (DBTs) are the major sulfur-containing compounds detected by GC-SCD. The GC-NCD and GC-SCD 
chromatograms of the analysed crude oils are presented in Figure 2 which clearly show alteration and removal of carbazoles, benzothiophenes, and dibenzothiophenes under severe biodegradation.
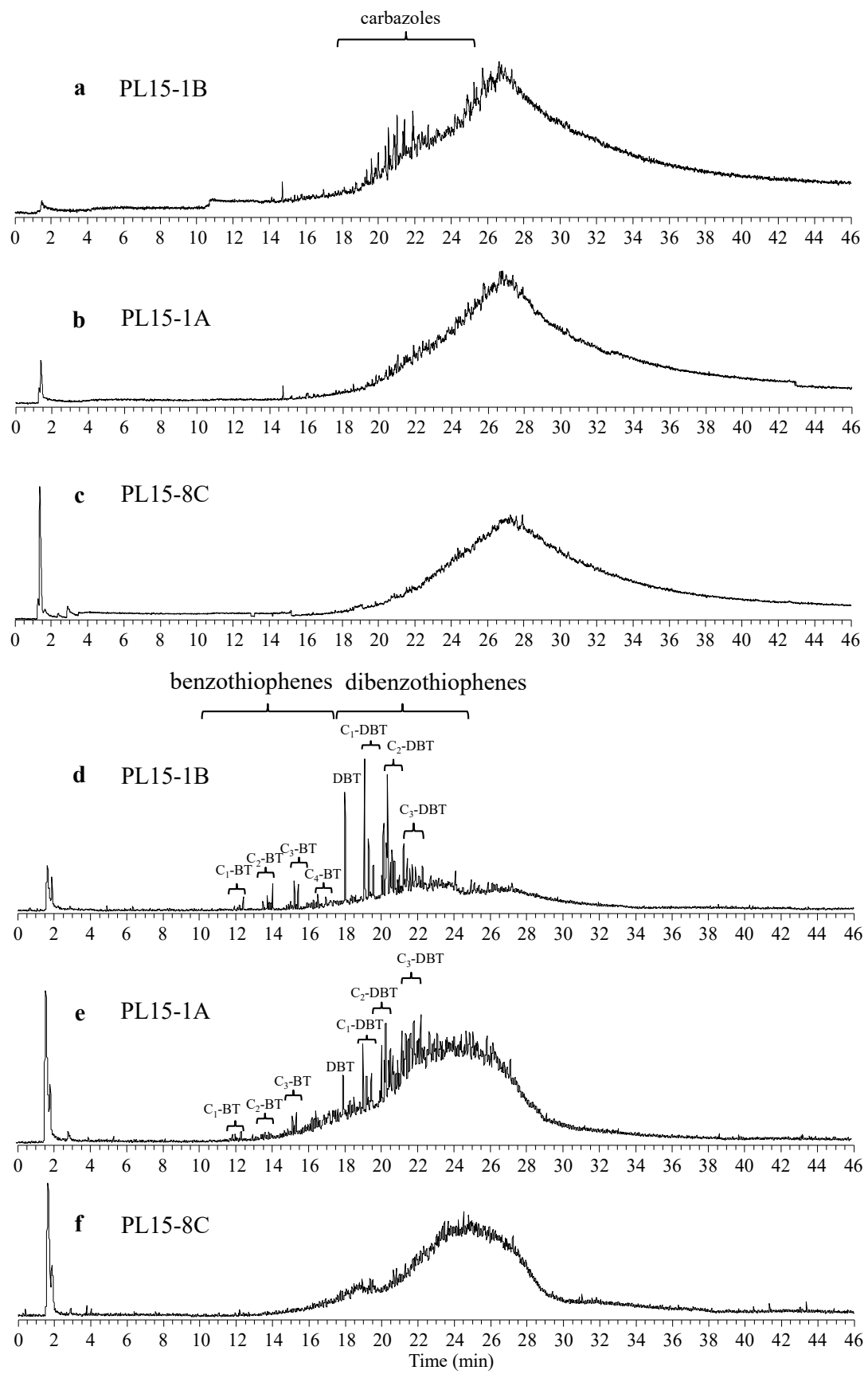

Figure 2. GC-NCD $(\mathbf{a}-\mathbf{c})$ and GC-SCD $(\mathbf{d}-\mathbf{f})$ chromatograms of the studied crude oils.

Intact carbazoles were present in the reference sample (PL15-1B oil) (Figure 2a), while only trace amounts of carbazoles appear to be left in the PL15-1A oil, as there were some minor peaks on the unresolved complex mixture (UCM) hump (Figure $2 b$ ). In the most severely biodegraded PL15-8C oil, carbazoles were completely removed, leaving a smooth UCM hump (Figure 2c). This observation is consistent with the report by Song et al. [43] in which carbazoles and benzocarbazoles were significantly removed at level 7 and above.

High abundance of $\mathrm{C}_{1}-\mathrm{C}_{4}$-BTs and $\mathrm{C}_{0}-\mathrm{C}_{3}$-DBTs occurred in the PL15-1B oil (Figure 2d). However, BTs and DBTs were substantially depleted in the PL15-1A oil, as evidenced by the less prominent peaks on the big UCM hump (Figure 2e); and these sulfur compounds 
were totally absent in the PL15-8C oil (Figure 2f). This is consistent with the GC-MS results of aromatic hydrocarbons documented in Cheng et al. [39], confirming progressive destruction of sulfur-containing aromatic hydrocarbons under severe biodegradation.

\subsection{Heteroatom Class Composition}

The analytical run conditions resulted in 2226, 2686, and 2339 resolved peaks in the PL15-1B oil, PL15-1A oil, and PL15-8C oil, respectively, and each of them was assigned a unique molecular formula with high confidence. The heteroatomic compounds identified in the oils were classified based on the type and number of heteroatoms. They include $\mathrm{O}_{1}-$ $\mathrm{O}_{5}, \mathrm{~N}_{1}, \mathrm{~N}_{2}, \mathrm{~N}_{1} \mathrm{O}_{1}, \mathrm{~N}_{1} \mathrm{O}_{2}, \mathrm{~N}_{1} \mathrm{O}_{3}, \mathrm{~N}_{1} \mathrm{~S}_{1}$, and $\mathrm{O}_{3} \mathrm{~S}_{1}$ classes. The $\mathrm{O}_{2}$ species were dominated by $\mathrm{C}_{16} \mathrm{H}_{32} \mathrm{O}_{2}$ and $\mathrm{C}_{18} \mathrm{H}_{36} \mathrm{O}_{2}$ with a DBE of 1 (interpreted as $\mathrm{C}_{16}$ and $\mathrm{C}_{18}$ fatty acids, respectively), which are very likely contaminants from the polypropylene tube of the ESI source [35]. The abundant $\mathrm{O}_{3} \mathrm{~S}_{1}$ classes dominated by $\mathrm{C}_{16}-\mathrm{C}_{19}$ with a DBE of 4 are alkylbenzene sulfonates and are well known as contaminants from drilling. Therefore, they were excluded in the data analysis.

The relative abundance of the heteroatomic classes was calculated by normalizing the peak intensity to the total intensity of all identified peaks in the mass spectra (Table 2). The bar charts showing the relative abundance (\%) of the 11 heteroatomic classes in the analysed crude oils are shown in Figure 3. In the PL15-1B oil, the $\mathrm{N}_{1}$ class $(77.4 \%)$ is the most abundant, followed by $\mathrm{O}_{1}(8.7 \%)$ and $\mathrm{O}_{2}(5.2 \%)$ classes, and the other classes are present at minor amounts (generally $<2.1 \%$, Figure $3 a$ ). In the severely biodegraded PL15-1A and PL15-8C oils, the relative abundance of the $\mathrm{N}_{1}$ compound class was sharply decreased to $52.9 \%$ and $35.1 \%$, respectively, indicating significant microbial alteration of this class. This is consistent with the results of the GC-NCD discussed above. A significant enrichment of $\mathrm{O}_{2}$ class was observed for the two severely biodegraded oils, suggesting formation of additional acidic compounds during microbial alteration of hydrocarbons. The relative abundance of the $\mathrm{O}_{3}, \mathrm{O}_{4}, \mathrm{O}_{5}, \mathrm{~N}_{2}, \mathrm{~N}_{1} \mathrm{O}_{1}$, and $\mathrm{N}_{1} \mathrm{~S}_{1}$ classes also tend to increase with increasing biodegradation (Figure $3 \mathrm{~b}$ ). This suggests that these compound classes are resistant to biodegradation. The decrease of $\mathrm{N}_{1} \mathrm{O}_{3}$ class with increasing biodegradation could be due to alteration during high levels of biodegradation. The relative abundance of the $\mathrm{N}_{1} \mathrm{O}_{2}$ compound class increased in the PL15-1A oil, but then decreased in the PL15-8C oil, which are not consistent with the increasing trend reported by other researchers $[33,35]$. The relative enrichment of the $\mathrm{N}_{1} \mathrm{O}_{2}$ species in the PL15-1A oil was due to preferential removal of other compounds, e.g., $\mathrm{N}_{1}$ species. The decrease of the $\mathrm{N}_{1} \mathrm{O}_{2}$ class could be attributed to destruction of this species under more extremely severe biodegradation conditions subjected by the PL15-8C oil.

Table 2. Relative abundance of heteroatomic compound classes in the studied crude oils.

\begin{tabular}{cccc}
\hline Species & PL15-1B & PL15-1B & PL15-8C \\
\hline $\mathrm{O}_{1}$ & 8.7 & 5.3 & 7.5 \\
$\mathrm{O}_{2}$ & 5.2 & 28.5 & 38.2 \\
$\mathrm{O}_{3}$ & 1.9 & 1.8 & 2.1 \\
$\mathrm{O}_{4}$ & 1.2 & 1.9 & 2.7 \\
$\mathrm{O}_{5}$ & 2.1 & 1.7 & 3.0 \\
$\mathrm{~N}_{1}$ & 77.4 & 52.9 & 35.1 \\
$\mathrm{~N}_{2}$ & 0.32 & 1.4 & 1.6 \\
$\mathrm{~N}_{1} \mathrm{O}_{1}$ & 0.77 & 0.69 & 1.04 \\
$\mathrm{~N}_{1} \mathrm{O}_{2}$ & 0.17 & 0.53 & 0.39 \\
$\mathrm{~N}_{1} \mathrm{O}_{3}$ & 0.56 & 0.24 & 0.19 \\
$\mathrm{~N}_{1} \mathrm{~S}_{1}$ & 1.7 & 5.0 & 8.2 \\
\hline
\end{tabular}



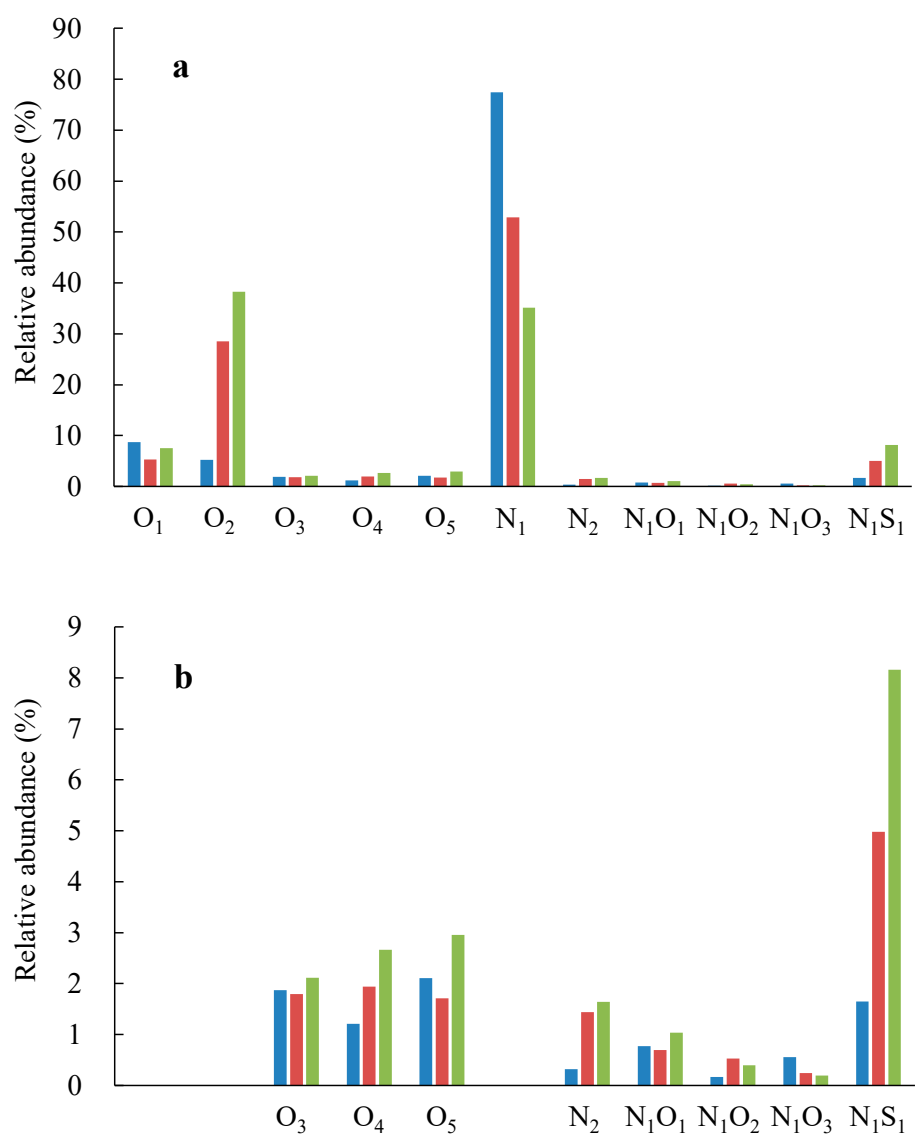

Figure 3. Bar graphs showing the relative abundance of heteroatomic classes assigned from the negative-ion ESI Orbitrap mass spectra of the studied crude oils with increasing biodegradation: (a) all the twelve heteroatomic classes; (b) the classes with low abundance.

\subsection{Alteration of Oxygen-Only Containing Classes}

\subsection{1. $\mathrm{O}_{1}$ Species}

Figure $4 \mathrm{a}-\mathrm{c}$ show the iso-abundance plots of DBE value versus carbon number for the $\mathrm{O}_{1}$ species in the studied crude oils. The $\mathrm{O}_{1}$ class has a carbon number range of 10-38 with DBE values of 4-24. In the PL15-1B oil, the $\mathrm{O}_{1}$ species are dominated by $\mathrm{C}_{19}, \mathrm{C}_{20}$, and $\mathrm{C}_{29}-\mathrm{C}_{31}$ compounds with a DBE of 16 , and those with DBE values of 5-7 and carbon numbers $<25$ are present at high relative abundance. In the PL15-1A oil, the $\mathrm{O}_{1}$ species is dominated by DBEs of $20\left(C_{28}\right.$ and $\left.C_{29}\right)$ and $16\left(C_{29}\right.$ and $\left.C_{31}\right)$, the components with DBE of 5-7 still have high relative abundance, while those with a DBE of 4 were significantly depleted. In the most severely biodegraded PL15-8C oil, the $\mathrm{O}_{1}$ species with DBEs $<20$ declined considerably in relative abundance leaving the $\mathrm{C}_{28}$ and $\mathrm{C}_{29}$ with a DBE of 20, showing an overwhelming predominance over other components.

$\mathrm{O}_{1}$ species that can be ionized by deprotonation under negative-ion ESI mode contain a hydroxyl group $[17,35]$. Because the $\mathrm{O}_{1}$ species with DBEs $<4$ were absent in the studies oils, the compounds with a DBE of 4 are most likely alkylphenols [33,44], and those with DBEs $\geq 5$ are considered to be phenols with additional naphthenic and/or aromatic rings $[33,44,45]$. The abundant $\mathrm{O}_{1}$ species with DBEs of 5-7 in the PL15-1B and PL15-1A oils could be a phenolic structure with a naphthenic ring, two naphthenic rings, and a benzene ring (i.e., naphthols), respectively; while, the prominent components with DBEs of 16 and 20 could contain fused aromatic rings. The gradual decrease in relative abundance of $\mathrm{O}_{1}$ species and the changes in the DBE values and carbon number predominance suggest that they are biodegradable, as proposed by Harwood et al. [46] and the $\mathrm{C}_{27}-\mathrm{C}_{30}$ compounds with a high DBE of 20 are extremely recalcitrant to severe biodegradation. 

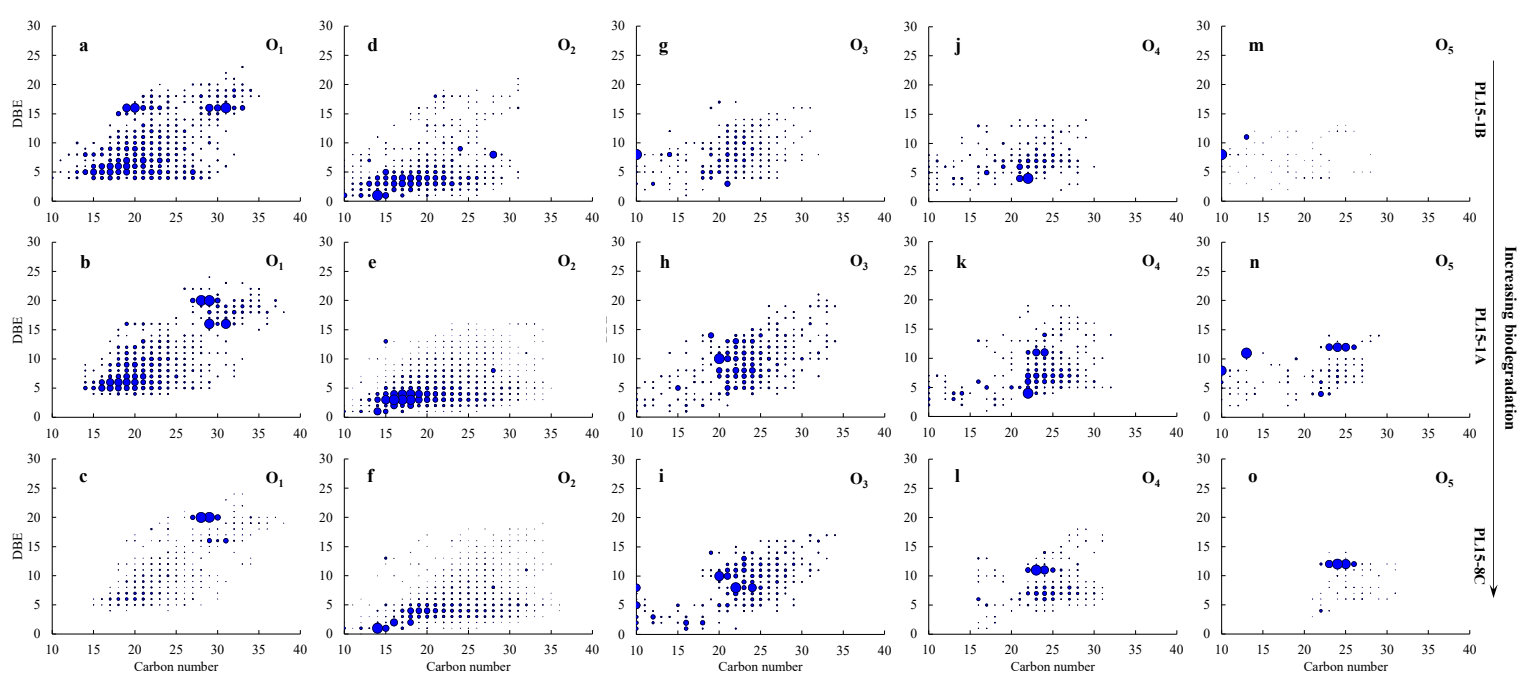

Figure 4. Iso-abundance plots of DBE versus carbon number of $\mathrm{O}_{1}-\mathrm{O}_{5}$ classes in the crude oils. The size of circles represents the relative abundance of the species in the spectra. $(\mathbf{a}-\mathbf{c}),(\mathbf{d}-\mathbf{f}),(\mathbf{g}-\mathbf{i}),(\mathbf{j}-\mathbf{l})$, and $(\mathbf{m}-\mathbf{o})$ show the distribution of $\mathrm{O}_{1}-\mathrm{O}_{5}$ classes for the PL15-1B, PL15-1A, and PL15-8C oils, respectively.

\subsection{2. $\mathrm{O}_{2}$ Species}

The $\mathrm{O}_{2}$ species with a DBE value of 1 are fatty acids, those with DBEs of 2-7 are thought to be 1-6-ring naphthenic acids, respectively, and those with higher DBE values could be polycyclic naphthenic acids, aromatic acids, or phenols with two hydroxyl groups [17,47,48]. As shown in Figure $4 \mathrm{~d}$,e, the DBE values of the $\mathrm{O}_{2}$ species in the crude oil samples mainly range from 1-18, and the carbon numbers are mainly of 10-31 for the PL15-1B oil and 10-34 for the PL15-1A and PL15-8C oils. The $\mathrm{O}_{2}$ species with DBEs of 3 and 4 (likely bicyclic and tricyclic naphthenic acids, respectively) and carbon number $<25$ are prominent in the PL15-1B and PL15-1A oils, while tricyclic acids (DBE $=4)$ are the most abundant, except the $C_{16}$ and $C_{18}$ monocyclic acids, in the PL15-8C oil. The tetracyclic $(\mathrm{DBE}=5)$ and pentacyclic $(\mathrm{DBE}=6)$ naphthenic acids, probably steroidal/secohopanoic acids and hopanoic acids, respectively, are present at low relative abundance in the oil samples analysed. This is consistent with that observed in severely biodegraded crude oils by Kim et al. [33].

Carboxylic acids are the most acidic components in petroleum; they are more easily ionized by negative-ion ESI source than less acidic neutral nitrogen compounds in organic solvents $[17,49]$. Therefore, carboxylic acids often dominate the negative-ion ESI mass spectra, especially, of biodegraded crude oils $[33,35,44]$. The $\mathrm{O}_{2}$ species were not abundant in our samples, although there was an increase in relative abundance of this compound class in the severely biodegraded PL15-1A oil (Figure 4e). The low abundance of $\mathrm{O}_{2}$ class compared with the $\mathrm{N}_{1}$ class indicate that the carboxylic acids must be present at very low absolute and relative abundance in the analysed oils.

Carboxylic acids in crude oils could be: (1) intermediates during oil generation [50,51], (2) biodegradation products of hydrocarbons [8,9,52-54], and (3) biosynthesised by microorganisms $[8,55]$. Previous analyses of biodegraded crude oils by negative-ion ESI FT-ICR MS generally show a dominance of the $\mathrm{O}_{2}$ species, which increase with increasing degree of biodegradation, and this change was usually attributed to transformation of hydrocarbons to acids during biodegradation [33,35,44]. This is supported by the observations that aerobic biodegradation of naphthenes via terminal oxidation [49,56,57]; and in some case anaerobic biodegradation of aromatic hydrocarbons [58-60] could generate naphthenic acids.

The predominance of bicyclic and tricyclic acids remained in the severely biodegraded oils, suggest that they, especially the tricyclics, are highly resistant to microbial alteration. High abundance of hopanoic acids were found in many biodegraded crude oils, and they were thought to be derived from oxidation of corresponding hopanes during aerobic 
biodegradation $[8,9,33,44]$. Intriguingly, hopanes were considerably altered in the PL15-1A oil and were almost completely destroyed in the PL15-8C oil, but there was no enrichment of hopanoic acids (Figure 4d,e). Similarly, no enrichment of 4-ring acids was observed with significant consumption of steranes in the two samples (Figure $4 \mathrm{~d}, \mathrm{e})$. These observations might suggest different biodegradation pathways rather than side chain oxidation for hopanes and steranes, which do not result in corresponding acids. A pathway of demethylation for hopanes could be possible in this case (Figure 5), as formation of 25-norhopane series was accompanied with the depletion of hopanes (Figure 1), while the biodegradation products of steranes are not clear. Alternatively, hopanoic acids were intermediates during biodegradation of hopanes, but they were further altered under severe biodegradation stage to yield 25-norhopanes by decarboxylation (Figure 5). This seems to be supported by the observations that (1) hopanoic acids increase with increasing biodegradation and reach maximum concentrations in the extensively biodegraded oils, and then rapidly decrease in severely biodegraded oils till absent [8], (2) 5-ring acids were prominent in heavily to severely biodegraded oils but were less abundant in the most severely altered oil [44], and (3) hopanoic acids (including 25-norhopanoic acids) are necessary intermediates in the generation of 25-norhopanes [61]. No doubt, further analysis of moderately and heavily biodegraded oils is necessary to account for the relationship between hopanes, 25-norhopanes and hopanoic acids and the biodegradation pathway of hopanes.

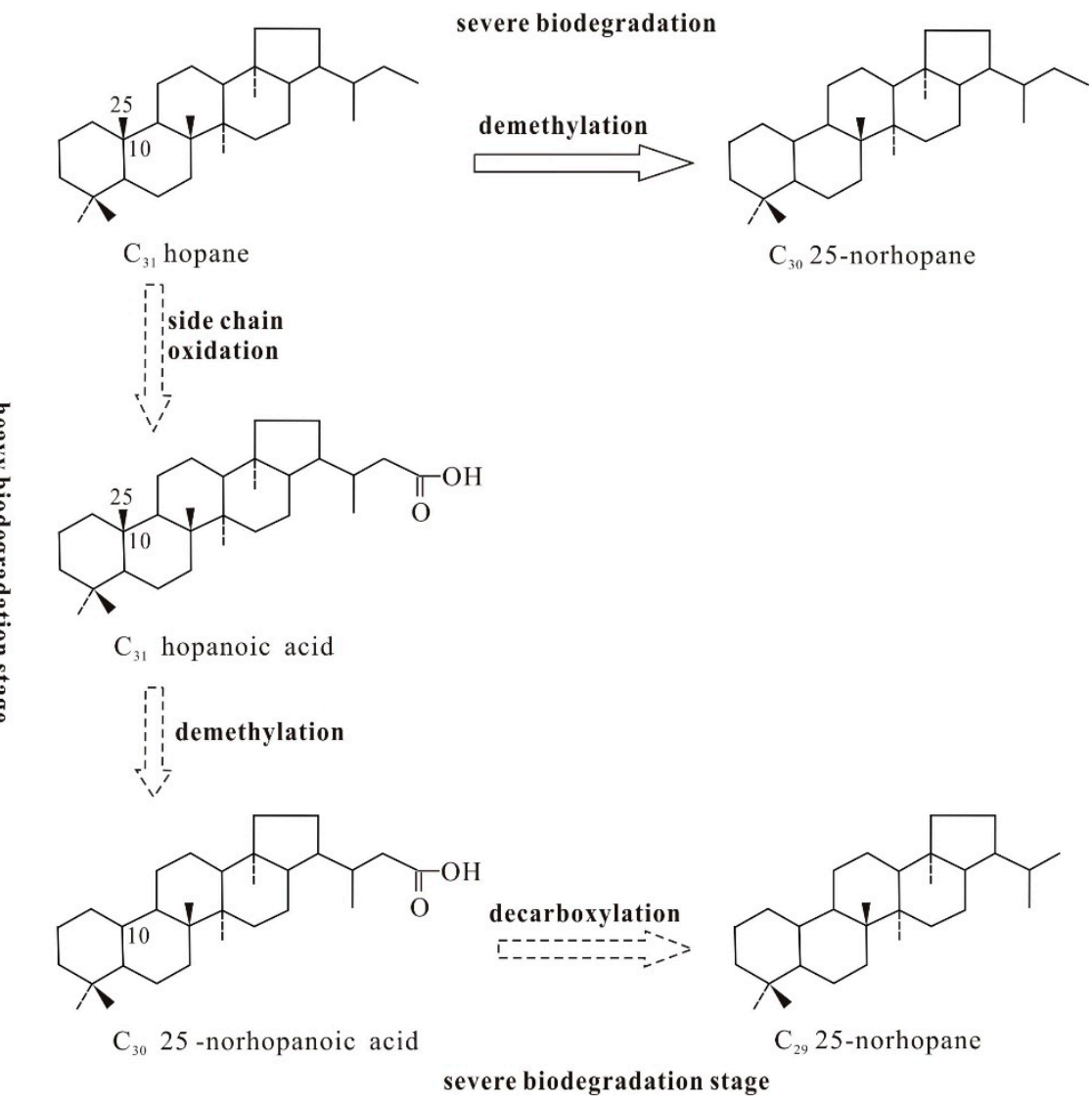

Figure 5. Putative biodegradation pathways of hopanes (taking $C_{31}$ hopane as an example).

\subsection{3. $\mathrm{O}_{3}-\mathrm{O}_{5}$ Species}

Figure $4 \mathrm{~g}-\mathrm{O}$ shows the iso-abundance plots of DBE versus carbon number for the $\mathrm{O}_{3}-\mathrm{O}_{5}$ species. The $\mathrm{O}_{3}$ species generally spread over carbon numbers of $10-34$ with a DBE range of 1-17 (Figure 4g-i). The components with carbon numbers of 20-25 and DBEs of 5-14 are of high relative abundance, especially for the severely biodegraded PL15-1A and PL15-8C oils. The $\mathrm{O}_{4}$ species in PL15-1B oil have carbon numbers of 10-30 and spread 
over a DBE range of 2-14, and are dominated by those with a DBE of 4 (Figure 4j). The $\mathrm{O}_{4}$ species in the PL15-1A oil have carbon numbers up to 32 and higher DBE values up to 19 , and those with DBE values of 7 and 11 are prominent components (Figure $4 \mathrm{k}$ ). In the PL15-8C oil, the $\mathrm{O}_{4}$ class with low carbon numbers $(\leq 15)$ are absent, and they are dominated by species with a DBE of 11 (Figure 41). The $\mathrm{O}_{5}$ species in PL15-1B oil have carbon numbers of 10-28 and spread over a DBE range of 2-13, and are dominated by $\mathrm{C}_{10} \mathrm{H}_{5} \mathrm{O}_{5}(\mathrm{DBE}=8)$ and $\mathrm{C}_{13} \mathrm{H}_{5} \mathrm{O}_{5}(\mathrm{DBE}=11)($ Figure $4 \mathrm{~m})$. The PL15-1A oil contains $\mathrm{O}_{5}$ species with similar carbon numbers and DBE values with that of the PL15-1B oil, but the $C_{23}-C_{26}$ compounds with a DBE of 12 were significantly enriched (Figure $4 n$ ). Much less $\mathrm{O}_{5}$ compounds, spreading from $\mathrm{C}_{21}$ to $\mathrm{C}_{31}$ with DBEs of 3-14, were identified in the PL15-8C oil, and the $C_{23}-C_{26}$ with a DBE of 12 have the largest concentration (Figure $4 \mathrm{o}$ ).

Overall, there is an evident preferential removal of $C_{20}$ - components and relative enrichment of $\mathrm{C}_{20+}$ compounds for the three classes. The continued decline of relative abundance of $\mathrm{O}_{3}-\mathrm{O}_{5}$ classes (Figure $3 \mathrm{~b}$ ) and the similar changes in carbon number distributions for each class with increasing extent of biodegradation (Figure $4 \mathrm{~g}-\mathrm{O}$ ) suggest that these oxygenated classes are susceptible to biodegradation. Among them, the low molecular weight components $\left(\mathrm{C}_{20-}\right)$ are less resistant to biodegradation.

\subsection{Alteration of Nitrogen-Containing Classes}

\subsection{1. $\mathrm{N}_{1}$ Species}

The $\mathrm{N}_{1}$ species in the slightly biodegraded PL15-1B oil have carbon numbers of 13-35 and DBEs of 7-22, and they are dominated by the compounds with DBE of 12 followed by 9 and 15 (Figure 6a). In contrast, the $\mathrm{N}_{1}$ species are dominated by DBE of 12 and 15 in the severely biodegraded PL15-1A and PL15-8C oils, respectively (Figure $6 \mathrm{~b}, \mathrm{c}$ ). The decrease in relative abundance of the $\mathrm{N}_{1}$ class (decrease from $77.4 \%$ to $52.9 \%$ and to $35.1 \%$ with increasing biodegradation) (Figure 3a) and the changes in predominance of DBE value and carbon numbers (Figure 6a-c) together with gradual removal of carbazoles in the crude oils with increasing biodegradation as characterized by GC-NCD (Figure 2), all definitely suggest microbial consumption of nitrogen-containing compounds rather than dilution by addition of other heteroatomic species (e.g., $\mathrm{O}_{3} \mathrm{~S}_{1}$ ) during severe biodegradation.
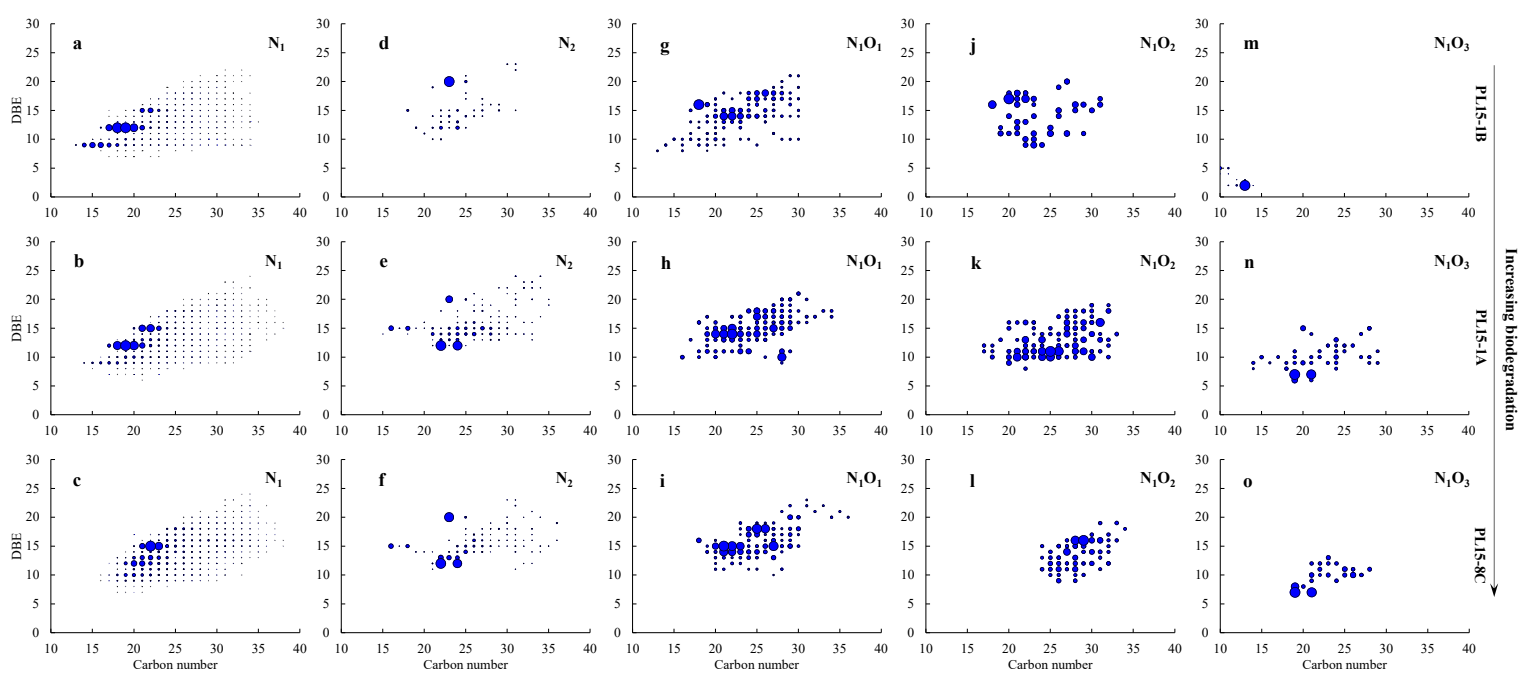

Figure 6. Iso-abundance plots of DBE versus carbon number of $\mathrm{N}_{1}, \mathrm{~N}_{2}$ and $\mathrm{N}_{1} \mathrm{O}_{1}-\mathrm{N}_{1} \mathrm{O}_{3}$ classes in the crude oils. (a-c), $(\mathbf{d}-\mathbf{f}),(\mathbf{g}-\mathbf{i}),(\mathbf{j}-\mathbf{l})$, and $(\mathbf{m}-\mathbf{o})$ show the distribution of $\mathrm{N}_{1}, \mathrm{~N}_{2}$ and $\mathrm{N}_{1} \mathrm{O}_{1}-\mathrm{N}_{1} \mathrm{O}_{3}$ classes for the PL15-1B, PL15-1A, and PL15-8C oils, respectively.

The $\mathrm{N}_{1}$ species ionized by negative-ion ESI source are neutral nitrogen compounds containing a pyrrolic structure $[17,21,34]$. This class with DBE values of 9,12 , and 15 are very likely carbazoles, benzocarbazoles, and dibenzocarbazoles, respectively [17,21,33,34,41]. 
Thus, the dominance of benzocarbazoles (DBE $=12)$ with abundant carbazoles (DBE $=9)$ in the PL15-1B oil shift to benzocarbazoles with high dibenzocarbazoles $(\mathrm{DBE}=15)$ in the PL15-1A oil, and to a dominance of dibenzocarbazoles in the PL15-8C oil (Figure 6a-c) indicate that these nitrogen-containing compounds with more fused aromatic rings are more resistant to biodegradation. This is consistent with the conclusions of previous studies based on both GC-MS and FTICR-MS analyses [33,44,62,63].

Previous studies have shown that carbazole analogs with longer alkyl side chains are preferentially biodegraded $[33,37,44]$. However, the $\mathrm{N}_{1}$ species with high carbon numbers $\left(\mathrm{C}_{35}-\mathrm{C}_{38}\right)$ and DBEs of $13-20$ are present in the two severely biodegraded crude oils; meanwhile, the $C_{13}-C_{15}$ and some $C_{30+}$ components with lower DBE values of 9-12 were absent (Figure $6 \mathrm{~b}, \mathrm{c}$ ). Therefore, we cannot draw a conclusion about the susceptibility of carbazole analogs to biodegradation regarding to their alkyl side chain length.

Additionally, accompanying the progressively decrease in relative abundance of carbazoles and benzocarbazoles, the $\mathrm{N}_{1}$ species with DBE values of 10 and 13 were gradually enhanced in relative abundance (Figure 6a-c). The components with a DBE of 10 might be phenylindoles or carbazoles with a naphthenic ring [35]; similarly, those with a DBE of 13 are probably benzocarbazoles with a naphthenic ring. The increase of their abundance relative to carbazoles and benzocarbazoles suggest that they are less susceptible to biodegradation than the latter.

\subsection{2. $\mathrm{N}_{2}$ Species}

The relative abundance of the $\mathrm{N}_{2}$ class is much less than the $\mathrm{N}_{1}$ class (Figure $3 \mathrm{a}$ ), and their distributions are more restricted regarding carbon number and DBE value than the latter (Figure $6 \mathrm{~d}-\mathrm{f}$ ). The $\mathrm{N}_{2}$ species in the PL15-1B oil range from $\mathrm{C}_{18}-\mathrm{C}_{31}$ with DBE values of $10-23$, and is dominated by $\mathrm{C}_{23} \mathrm{H}_{9} \mathrm{~N}_{2}(\mathrm{DBE}=20)$. The $\mathrm{N}_{2}$ species with higher carbon numbers (up to $C_{35}$ and $C_{36}$, respectively) were identified in the PL15-1A and PL15$8 \mathrm{C}$ oils, and they are dominated by $\mathrm{C}_{22} \mathrm{H}_{23} \mathrm{~N}_{2}$ and $\mathrm{C}_{24} \mathrm{H}_{27} \mathrm{~N}_{2}(\mathrm{DBE}=12)$ and $\mathrm{C}_{23} \mathrm{H}_{9} \mathrm{~N}_{2}$ $(\mathrm{DBE}=20)$. The compounds with DBEs of 14 and 15 are relatively abundant in the PL151A oil (Figure 6e), but this was not seen in the PL15-8C oil (Figure 6f). Although the Orbitrap MS has high mass resolution and mass accuracy, an elucidation of the molecular structure is not possible. However, the changes in distribution of the prominent compounds and relative abundance with increasing biodegradation confirm microbial alteration of this class.

\subsection{3. $\mathrm{N}_{1} \mathrm{O}_{1}-\mathrm{N}_{1} \mathrm{O}_{3}$ Species}

Oxygenated nitrogen compounds, including $\mathrm{N}_{1} \mathrm{O}_{1}, \mathrm{~N}_{1} \mathrm{O}_{2}$, and $\mathrm{N}_{1} \mathrm{O}_{3}$ classes, were present in the analysed oils. For the $\mathrm{N}_{1} \mathrm{O}_{1}$ species, the components with DBEs of 14, 15,17 , and 18 are relatively abundant in the studied oils (Figure 6g-i). With increasing biodegradation, the species with low carbon numbers $\left(<\mathrm{C}_{20}\right)$ were gradually depleted and those with DBEs of 15 and 18 were progressively enriched (Figure 6g-i). This compositional change together with the decline of relative abundance of this class with biodegradation suggest that the $\mathrm{N}_{1} \mathrm{O}_{1}$ species were further altered during severe biodegradation and those with DBEs of 15 and 18 were more recalcitrant to biodegradation.

The $\mathrm{N}_{1} \mathrm{O}_{2}$ species generally spread over a DBE range of 9-19 and carbon numbers of 17-34, except for the PL15-8C oil in which the carbon numbers $\geq 24$ (Figure 6j-1). No prominent components were observed in the PL15-1B oil (Figure 6j). The compounds with a DBE of 11 were relatively prominent in the PL15-1A oil (Figure 6k), while this feature disappeared in the PL15-8C oil (Figure 61). In addition, the low carbon number components were removed from the PL15-8C oil (Figure 61). From the iso-abundance plot, the dots for $\mathrm{N}_{1} \mathrm{O}_{2}$ compounds in the PL15-1A oil are more than that in the other two oil samples. This appears to be consistent with the increase in relative abundance of the $\mathrm{N}_{1} \mathrm{O}_{2}$ class in the PL15-1A oil and then decrease in the PL15-8C oil (Figure 3b). These observations suggest that some $\mathrm{N}_{1} \mathrm{O}_{2}$ compounds, especially those with a DBE of 11 , were newly generated in 
the PL15-1A oil, while the species with low carbon numbers and low DBE values were selectively biodegraded in the PL15-8C oil.

The carbon number and DBE value of the $\mathrm{N}_{1} \mathrm{O}_{3}$ class vary significantly from the three analysed samples (Figure $6 \mathrm{~m}-\mathrm{O}$ ). For the PL15-1B oil, the $\mathrm{N}_{1} \mathrm{O}_{3}$ species are in the range of $\mathrm{C}_{10}-\mathrm{C}_{14}$ with DBE values of 2-5; in the PL15-1A oil, they range from $\mathrm{C}_{14}-\mathrm{C}_{29}$ with DBEs of 6-15; and in the PL15-8C oil, they range from $C_{19}-C_{28}$ with DBEs of 7-13. In the two severely biodegraded oils, $\mathrm{C}_{19} \mathrm{H}_{26} \mathrm{~N}_{1} \mathrm{O}_{3}$ and $\mathrm{C}_{21} \mathrm{H}_{30} \mathrm{~N}_{1} \mathrm{O}_{3}(\mathrm{DBE}=7)$ became dominant (Figure $6 n, o$ ). The occurrence of the $\mathrm{N}_{1} \mathrm{O}_{3}$ species with different carbon numbers and DBE values in the severely biodegraded oils compared with the reference PL15-1B oil indicate that some species in this class were altered, while some components were generated during severe biodegradation.

Oxygenated nitrogen compounds in petroleum may be furollic, phenolic, or contain carboxylic functional groups $[17,21,33,64]$. The $\mathrm{N}_{1} \mathrm{O}_{1}$ and $\mathrm{N}_{1} \mathrm{O}_{2}$ species could have originated from of $\mathrm{N}_{1}$ compounds under both aerobic or anaerobic biodegradation $[33,37,65]$. Varying biodegradation pathways of carbazoles have been documented in the literature, for example, (1) lateral dioxygenation of carbazole yielding 4-(30-hydroxy-20-indoyl)-2oxo-3-butenoic acid $\left(\mathrm{N}_{1} \mathrm{O}_{4}\right)$ [66], (2) angular dioxygenation of carbazole generating 2'aminobiphenyl-2,3-diol $\left(\mathrm{N}_{1} \mathrm{O}_{2}\right)$ with the DBE value decrease by $1[67,68],(3)$ hydroxylation of carbazole to form 1-, 2- and 3-hydroxycarbazoles $\left(\mathrm{N}_{1} \mathrm{O}_{1}\right.$, without change of the DBE value) [69-71], and (4) ring-opening reaction to yield 2'-aminobiphenyl-2-ol $\left(\mathrm{N}_{1} \mathrm{O}_{1}\right)$ with a decrease of DBE value by $1[33,44]$.

It is plausible that benzocarbazoles, dibenzocarbazoles, and benzonaphthocarbazoles could be biodegraded via similar pathways of carbazoles. Shi et al. [41] suggested that the oxygen in the $\mathrm{N}_{1} \mathrm{O}_{1}$ species is more likely in the form of hydroxyl rather than a furanlike cyclic ether group. The relatively abundant $\mathrm{N}_{1} \mathrm{O}_{1}$ species with DBEs of 14 and 17 present in the PL15-1A oil, therefore, might be transformed from ring-opening reaction of dibenzocarbazoles and benzonaphthocarbazoles, respectively; while the $\mathrm{N}_{1} \mathrm{O}_{1}$ compounds with DBEs of 15 and 18 might be hydroxydibenzocarbazoles and hydroxybenzonaphthocarbazoles derived from dibenzocarbazoles and benzonaphthocarbazoles, respectively, via a hydroxylation pathway. The dominance of $\mathrm{N}_{1} \mathrm{O}_{1}$ species with DBEs of 15 and 18 in the PL15-8C oil imply preferential hydroxylation pathway versus ring-opening pathway for dibenzocarbazoles and benzonaphthocarbazoles biodegradation during very severe biodegradation; alternatively, the compounds with DBEs of 15 and 18 are more resistant to biodegradation than those with DBEs of 14 and 17.

The $\mathrm{N}_{1} \mathrm{O}_{2}$ species could contain a carboxyl or two hydroxyl groups, and other functional groups with oxygen are also possible $[41,49,65]$. The relatively abundant $\mathrm{N}_{1} \mathrm{O}_{2}$ species with a DBE of 11 in the PL15-1A oil could be biodegradation products of benzocarbazoles via angular deoxygenation $[67,68]$. However, $\mathrm{N}_{1} \mathrm{O}_{2}$ species were present at very low abundance relative to the $\mathrm{N}_{1}$ class and they did not show evident DBE dominance and wide ranges of $\mathrm{DBE}$ and carbon number as the $\mathrm{N}_{1}$ class, suggesting that the composition and origin of $\mathrm{N}_{1} \mathrm{O}_{2}$ class are complicated. Further analysis of the $\mathrm{N}_{1} \mathrm{O}_{2}$ compounds is needed to elucidate their structures in the future.

Although the $\mathrm{N}_{1} \mathrm{O}_{3}$ species also widely occurred in biodegraded crude oils, they were less studied than the $\mathrm{N}_{1} \mathrm{O}_{1}$ and $\mathrm{N}_{1} \mathrm{O}_{2}$ species. Theoretically, the three oxygen atoms could be present in multiple forms, such as hydroxyl, carboxyl, cyclic ether, and carbonyl groups, which can form various combinations. In addition, the distributions of carbon numbers and DBE values of $\mathrm{N}_{1} \mathrm{O}_{3}$ class are different from that of the $\mathrm{N}_{1} \mathrm{O}_{1}$ and $\mathrm{N}_{1} \mathrm{O}_{2}$ species, but fall in the range of the $\mathrm{N}_{1}$ class. Therefore, the newly generated $\mathrm{N}_{1} \mathrm{O}_{3}$ species could originate from bioconversion of the $\mathrm{N}_{1}$ species. However, the molecular structure of the $\mathrm{N}_{1} \mathrm{O}_{3}$ compounds cannot be ascertained only based on their molecular formulae and DBE values. 


\subsection{Alteration of Sulfur-Containing Classes}

\subsection{1. $\mathrm{N}_{1} \mathrm{~S}_{1}$ Species}

In the studied oils, the $\mathrm{N}_{1} \mathrm{~S}_{1}$ and $\mathrm{O}_{3} \mathrm{~S}_{1}$ are the only two heteroatomic compound types which contain a sulfur atom (Figure 3 ). The $\mathrm{N}_{1} \mathrm{~S}_{1}$ species contain carbon numbers ranging from 10-32, 10-35 and 10-36 with DBEs of 4-16, 5-21 and 5-21 in the PL15-1B, PL15-1A and PL15-8C oils, respectively (Figure 7a-c). For the PL15-1B oil, the $\mathrm{N}_{1} \mathrm{~S}_{1}$ compounds were dominated by a few dots in the iso-abundance plot. Two compounds with a DBE of 8 $\left(\mathrm{C}_{22} \mathrm{H}_{30} \mathrm{~N}_{1} \mathrm{~S}_{1}\right.$ and $\left.\mathrm{C}_{24} \mathrm{H}_{34} \mathrm{~N}_{1} \mathrm{~S}_{1}\right)$ became dominant in the PL15-1A oil; and the components with DBEs of 10 and 11 are also present at relatively high abundance (Figure $7 \mathrm{~b}$ ). The relative abundance of the components with DBEs of 10 and 11 were depleted in the PL15-8C oil, leaving a $\mathrm{C}_{22}$ and a $\mathrm{C}_{24}$ compound with a DBE of 8 became more prominent (Figure 7c).
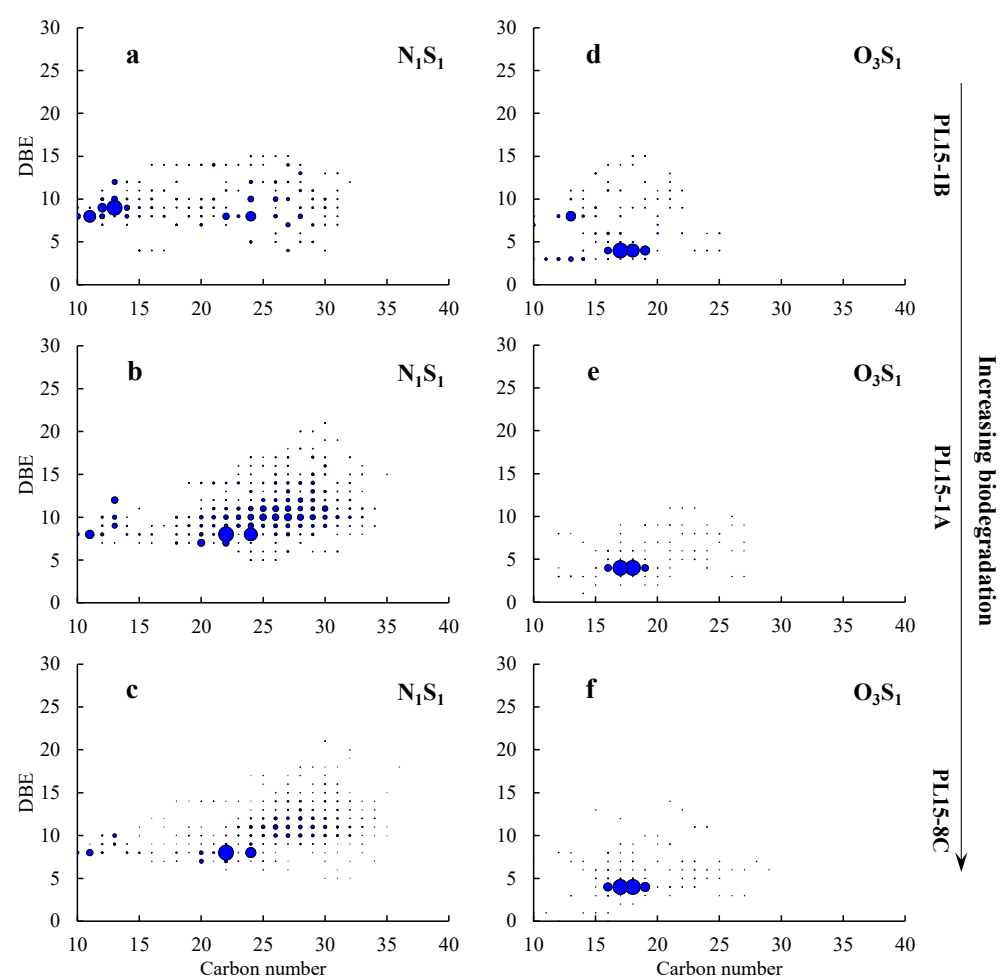

Figure 7. Iso-abundance plots of DBE versus carbon number of $\mathrm{N}_{1} \mathrm{~S}_{1}$ and $\mathrm{O}_{3} \mathrm{~S}_{1}$ classes in the crude oils. (a-c) show the $\mathrm{N}_{1} \mathrm{~S}_{1}$ class for the PL15-1B, PL15-1A, and PL15-8C oils, respectively, and (d-f) show the $\mathrm{O}_{3} \mathrm{~S}_{1}$ class for the PL15-1B, PL15-1A, and PL15-8C oils, respectively.

Due to the ionization mechanism of negative-ion ESI source, only neutral nitrogencontaining and acid sulfur-containing compounds can be ionized, while basic nitrogen and neutral and basic sulfur compounds are excluded [17,34,41]. Thus, the $\mathrm{N}_{1} \mathrm{~S}_{1}$ species in the samples should contain a pyrrolic structure. The species with DBEs of 8 and 11 could contain the substructures of indole and carbazole, respectively, fused with thiophene or combined with a two-ring cyclic sulfide, while the compounds with a DBE of 10 could contain a carbazole substructure with a saturated sulfur ring. The occurrence of these compounds in the severely biodegraded crude oils suggest that they are highly resistant to biodegradation.

\subsubsection{Benzothiophenes and Dibenzothiophenes}

As discussed in Section 3.1, benzothiophenes and dibenzothiophenes were considerably consumed in the PL15-1A oil and they were removed from the PL15-8C oil (Figure 2e,f). The absence of $\mathrm{O}_{x} \mathrm{~S}_{1}$ species except those $\mathrm{O}_{3} \mathrm{~S}_{1}$ contaminants in the analysed oil samples, therefore, suggests that benzothiophenes and dibenzothiophenes were not bio-transformed 
to oxygenated sulfur compounds containing hydroxyl or carboxyl groups, which can be ionized by negative-ion ESI source.

Previous studies show that there are three pathways for biodegradation of dibenzothiophene: (1) the ring-destructive pathway, i.e., the "Kodama pathway", in which one of the benzene rings of DBT is oxidized and cleaved to yield 3-hydroxy-2-formylbenzothiophene as the major product [72,73]; (2) the complete pathway, in which DBT is mineralized to sulfite, carbon dioxide, and water [74]; and (3) the sulfur-specific pathway, usually called

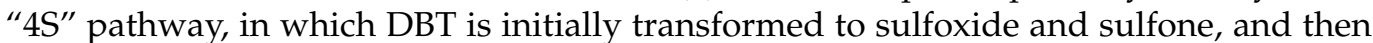
these intermediates are further oxidized to yield sulfate, 2-hydroxybiphenyl and/or 2,2'dihydroxybiphenyl $[75,76]$. As reviewed by Ei-Gendy and Nassar [77], benzothiophenes can be altered by similar pathways to yield sulfur-containing metabolites, such as 2,3-dione, sulfoxide, sulfone, and carboxylic acid. Thus, we tentatively infer that benzothiophenes and dibenzothiophenes were biodegraded by the complete pathway or the sulfur-specific pathway. However, further analysis of neutral and basic sulfur containing compounds by positive-ion ESI Orbitrap MS or FT-ICR MS might provide more details on biodegradation mechanism of benzothiophenes and dibenzothiophenes.

\section{Conclusions}

Negative-ion ESI Orbitrap MS analysis of a slightly and two severely biodegraded crude oils with the same origin showed that the neutral and acidic polar NSO compounds consist of $\mathrm{O}_{1}-\mathrm{O}_{5}, \mathrm{~N}_{1}, \mathrm{~N}_{2}, \mathrm{~N}_{1} \mathrm{O}_{1}-\mathrm{N}_{1} \mathrm{O}_{3}, \mathrm{~N}_{1} \mathrm{~S}_{1}$ and $\mathrm{O}_{3} \mathrm{~S}_{1}$ species. Microbial alteration was observed to occur in most compound classes with preferential consumption of the $\mathrm{N}_{1}$ species based on their compositional changes with increasing degree of biodegradation.

The $\mathrm{O}_{1}$ species are likely alkylphenols with additional naphthenic and/or aromatic rings, and are readily altered during severe biodegradation. The $\mathrm{O}_{2}$ species in the crude oil samples are mainly carboxylic acids. They originated during bioconversion of hydrocarbons. The dominance of $\mathrm{O}_{2}$ species with DBEs of 3-4, which are thought to be 2-3-ring naphthenic acids, in the severely biodegraded oils suggest that they are newly formed and are highly recalcitrant to biodegradation. Hopanes in our samples could be biodegraded by demethylation or via unstable hopanoic acids as intermediates to form 25-norhopanes, because hopanoic acids were not observed to increase in the severely biodegraded oils. The $\mathrm{O}_{3}-\mathrm{O}_{5}$ species were biodegraded under severe conditions with preferential removal of low molecular weight components $\left(\mathrm{C}_{20-}\right)$.

The slightly biodegraded PL15-1B oil is dominated by the $\mathrm{N}_{1}$ species, which contains a pyrrolic structure and varying numbers of aromatic and/or naphthenic rings. They were substantially altered under severe biodegradation as being consistent with the removal of indoles and carbazoles revealed by GC-NCD analysis. The $\mathrm{N}_{1}$ species could be biotransformed to $\mathrm{N}_{1} \mathrm{O}_{1}-\mathrm{N}_{1} \mathrm{O}_{3}$ species via hydroxylation, ring-opening, and other unknow pathways, and these oxygenated nitrogen compounds were further altered.

The $\mathrm{N}_{1} \mathrm{~S}_{1}$ species in the oils could contain a pyrrolic structure and they are highly resistant to biodegradation. GC-SCD data show substantial removal of benzothiophenes and dibenzothiophenes in the two severely biodegraded crude oils, but without generation of corresponding acidic oxygenated sulfur compounds. This could be attributed to a complete pathway or a sulfur-specific pathway for biodegradation of benzothiophenes and dibenzothiophenes.

Author Contributions: Conceptualization, X.C.; methodology, X.C.; validation, X.C. and D.H.; formal analysis, X.C.; investigation, X.C.; data curation, X.C.; writing-original draft preparation, X.C.; writing-review and editing, X.C. and D.H.; visualization, X.C.; supervision, D.H.; project administration, D.H. and X.C.; funding acquisition, X.C. and D.H. All authors have read and agreed to the published version of the manuscript.

Funding: This research was funded by the National Science and Technology Major Project, grant number 2016ZX05027-001-003, National Natural Science Foundation of China, grant number 41872131, China Postdoctoral Science Foundation, grant number 2019M660735, and Fundamental Research Funds for the Central Universities, grant number 2-9-2019-013. 
Institutional Review Board Statement: Not applicable.

Informed Consent Statement: Not applicable.

Data Availability Statement: The data presented in this study are available on request from the corresponding author.

Acknowledgments: Quan Shi (China University of Petroleum, Beijing) is acknowledged for negativeion ESI Orbitrap MS analysis of the samples. We would like to thank three anonymous referees for constructive comments which helped to improve the manuscript.

Conflicts of Interest: The authors declare no conflict of interest.

\section{References}

1. Milner, C.W.D.; Rogers, M.A.; Evans, C.R. Petroleum transformations in reservoirs. J. Geochem. Explor. 1977, 7, 101-153. [CrossRef]

2. Volkman, J.K.; Alexander, R.; Kagi, R.I.; Woodhouse, G.W. Demethylated hopanes in crude oils and their applications in petroleum geochemistry. Geochim. Cosmochim. Acta 1983, 47, 785-794. [CrossRef]

3. Peters, K.E.; Walters, C.C.; Moldowan, J.M. The Biomarker Guide 2. Biomarkers and Isotopes in Petroleum Exploration and Earth History; Cambridge University Press: New York, NY, USA, 2005.

4. Wenger, L.M.; Davis, C.L.; Isaksen, G.H. Multiple controls on petroleum biodegradation and impact on oil quality. SPE Reserv. Eval. Eng. 2002, 5, 375-383. [CrossRef]

5. Widdel, F.; Rabus, R. Anaerobic biodegradation of saturated and aromatic hydrocarbons. Curr. Opin. Biotech. 2001, 12, 259-276. [CrossRef]

6. Moldowan, J.M.; McCaffrey, M.A. A novel microbial hydrocarbon degradation pathway revealed by hopane demethylation in a petroleum reservoir. Geochim. Cosmochim. Acta 1995, 59, 1891-1894. [CrossRef]

7. Meckenstock, R.U.; Boll, M.; Mouttaki, H.; Koelschbach, J.S.; Cunha Tarouco, P.; Weyrauch, P.; Dong, X.; Himmelberg, A.M. Anaerobic degradation of benzene and polycyclic aromatic hydrocarbons. Microb. Physiol. 2016, 26, 92-118. [CrossRef]

8. Meredith, W.; Kelland, S.J.; Jones, D.M. Influence of biodegradation on crude oil acidity and carboxylic acid composition. Org. Geochem. 2000, 31, 1059-1073. [CrossRef]

9. Watson, J.S.; Jones, D.M.; Swannell, R.P.J; van Duin, A.C.T. Formation of carboxylic acids during aerobic biodegradation of crude oil and evidence of microbial oxidation of hopanes. Org. Geochem. 2002, 33, 1153-1169. [CrossRef]

10. Behar, F.H.; Albrecht, P. Correlations between carboxylic acids and hydrocarbons in several crude oils. Alter. Biodegrad. Org. Geochem. 1984, 6, 597-604. [CrossRef]

11. Marshall, A.G.; Hendrickson, C.L.; Jackson, G.S. Fourier transform ion cyclotron resonance mass spectrometry: A primer. Mass Spectrom. Rev. 1998, 17, 1-35. [CrossRef]

12. Rodgers, R.P.; Marshall, A.G. Petroleomics: Advanced characterization of petroleum-derived materials by fourier transform ion cyclotron resonance mass spectrometry (FT-ICR MS). In Asphaltenes, Heavy Oils, and Petroleomics; Mullins, O.C., Sheu, E.Y., Hammami, A., Marshall, A.G., Eds.; Springer: New York, NY, USA, 2007; pp. 63-93.

13. Hu, Q.; Noll, R.J.; Li, H.; Makarov, A.; Hardman, M.; Graham Cooks, R. The Orbitrap: A new mass spectrometer. J. Mass Spectrom. 2005, 40, 430-443. [CrossRef]

14. Schmidt, E.M.; Pudenzi, M.A.; Santos, J.M.; Angolini, C.F.F.; Pereira, R.C.L.; Rocha, Y.S.; Denisov, E.; Damoc, E.; Makarov, A.; Eberlin, M.N. Petroleomics via Orbitrap mass spectrometry with resolving power above 1000000 at m/z 200. RSC Adv. 2018, 8, 6183-6191. [CrossRef]

15. Hughey, C.A.; Hendrickson, C.L.; Rodgers, R.P.; Marshall, A.G. Elemental composition analysis of processed and unprocessed diesel fuel by electrospray ionization fourier transform ion cyclotron resonance mass spectrometry. Energy Fuels 2001, 15, 1186-1193. [CrossRef]

16. Qian, K.; Rodgers, R.P.; Hendrickson, C.L.; Emmett, M.R.; Marshall, A.G. Reading chemical fine print: Resolution and identification of 3000 nitrogen-containing aromatic compounds from a single electrospray ionization Fourier transform ion cyclotron resonance mass spectrum of heavy petroleum crude oil. Energy Fuels 2001, 15, 492-498. [CrossRef]

17. Hughey, C.A.; Rodgers, R.P.; Marshall, A.G.; Qian, K.; Robbins, W.K. Identification of acidic NSO compounds in crude oils of different geochemical origins by negative ion electrospray Fourier transform ion cyclotron resonance mass spectrometry. Org. Geochem. 2002, 33, 743-759. [CrossRef]

18. Liu, P.; Shi, Q.; Chung, K.H.; Zhang, Y.; Pan, N.; Zhao, S.; Xu, C. Molecular characterization of sulfur compounds in Venezuela crude oil and its SARA fractions by electrospray ionization fourier transform ion cyclotron resonance mass spectrometry. Energy Fuels 2010, 24, 5089-5096. [CrossRef]

19. Wan, Z.; Li, S.; Pang, X.; Dong, Y.; Wang, Z.; Chen, X.; Meng, X.; Shi, Q. Characteristics and geochemical significance of heteroatom compounds in terrestrial oils by negative-ion electrospray Fourier transform ion cyclotron resonance mass spectrometry. Org. Geochem. 2017, 111, 34-55. [CrossRef]

20. Ji, H.; Li, S.; Greenwood, P.; Zhang, H.; Pang, X.; Xu, T.; He, N.; Shi, Q. Geochemical characteristics and significance of heteroatom compounds in lacustrine oils of the Dongpu Depression (Bohai Bay Basin, China) by negative-ion Fourier transform ion cyclotron resonance mass spectrometry. Mar. Pet. Geol. 2018, 97, 568-591. [CrossRef] 
21. Hughey, C.A.; Rodgers, R.P.; Marshall, A.G.; Walters, C.C.; Qian, K.; Mankiewicz, P. Acidic and neutral polar NSO compounds in Smackover oils of different thermal maturity revealed by electrospray high field Fourier transform ion cyclotron resonance mass spectrometry. Org. Geochem. 2004, 35, 863-880. [CrossRef]

22. dos Santos Rocha, Y.; Pereira, R.C.L.; Mendonça Filho, J.G. Negative electrospray Fourier transform ion cyclotron resonance mass spectrometry determination of the effects on the distribution of acids and nitrogen-containing compounds in the simulated thermal evolution of a Type-I source rock. Org. Geochem. 2018, 115, 32-45.

23. Han, Y.; Poetz, S.; Mahlstedt, N.; Karger, C.; Horsfield, B. Fractionation and origin of NyOx and Ox compounds in the Barnett Shale sequence of the Marathon 1 Mesquite well, Texas. Mar. Pet. Geol. 2018, 97, 517-524. [CrossRef]

24. Han, Y.; Poetz, S.; Mahlstedt, N.; Karger, C.; Horsfield, B. Fractionation of pyrrolic nitrogen compounds compounds during primary migration of petroleum within the barnett shale sequence of marathon 1 Mesquite well, Texas. Energy Fuels 2018, 32, 4638-4650. [CrossRef]

25. Liu, P.; Li, M.; Jiang, Q.; Cao, T.; Sun, Y. Effect of secondary oil migration distance on composition of acidic NSO compounds in crude oils determined by negative-ion electrospray Fourier transform ion cyclotron resonance mass spectrometry. Org. Geochem. 2015, 78, 23-31. [CrossRef]

26. Ventura, G.T.; Rossel, P.E.; Simoneit, B.R.T.; Dittmar, T. Fourier transform ion cyclotron resonance mass spectrometric analysis of NSO-compounds generated in hydrothermally altered sediments from the Escanaba Trough, northeastern Pacific Ocean. Org. Geochem. 2020, 149, 104085. [CrossRef]

27. Gomez-Saez, G.V.; Niggemann, J.; Dittmar, T.; Pohlabeln, A.M.; Lang, S.Q.; Noowong, A.; Pichler, T.; Wörmer, L.; Bühring, S.I. Molecular evidence for abiotic sulfurization of dissolved organic matter in marine shallow hydrothermal systems. Geochim. Cosmochim. Acta 2016, 190, 35-52. [CrossRef]

28. Yang, C.; Zhang, G.; Serhan, M.; Koivu, G.; Yang, Z.; Hollebone, B.; Lambert, P.; Brown, C.E. Characterization of naphthenic acids in crude oils and refined petroleum products. Fuel 2019, 255, 115849. [CrossRef]

29. Liu, Y.; Huang, H.; Liu, Q.; Xu, X.; Cheng, H. The acid and neutral nitrogen compounds characterized by negative ESI Orbitrap MS in a heavy oil before and after oxidation. Fuel 2020, 277, 118085. [CrossRef]

30. Xia, Y.; Ma, C.; Ju, R.; Zhao, C.; Zheng, F.; Sun, X.; Li, Z.; Wang, C.; Shi, D.; Lin, X.; et al. Characterization of nitrogen-containing compounds in petroleum fractions by online reversed-phase liquid chromatography-electrospray ionization Orbitrap mass spectrometry. Fuel 2021, 284, 119035. [CrossRef]

31. Rodrigues Covas, T.; Santos de Freitas, C.; Valadares Tose, L.; Valencia-Dávila, J.A.; dos Santos Rocha, Y.; Duncan Rangel, M.; Cabral da Silva, R.; Gontijo Vaz, B. Fractionation of polar compounds from crude oils by hetero-medium pressure liquid chromatography (H-MPLC) and molecular characterization by ultrahigh-resolution mass spectrometry. Fuel 2020, $267,117289$. [CrossRef]

32. Ghaste, M.; Mistrik, R.; Shulaev, V. Applications of fourier transform ion cyclotron resonance (FT-ICR) and orbitrap based high resolution mass spectrometry in metabolomics and lipidomics. Int. J. Mol. Sci. 2016, 17, 816. [CrossRef]

33. Kim, S.; Stanford, L.A.; Rodgers, R.P.; Marshall, A.G.; Walters, C.C.; Qian, K.; Wenger, L.M.; Mankiewicz, P. Microbial alteration of the acidic and neutral polar NSO compounds revealed by Fourier transform ion cyclotron resonance mass spectrometry. Org. Geochem. 2005, 36, 1117-1134. [CrossRef]

34. Hughey, C.A.; Galasso, S.A.; Zumberge, J.E. Detailed compositional comparison of acidic NSO compounds in biodegraded reservoir and surface crude oils by negative ion electrospray Fourier transform ion cyclotron resonance mass spectrometry. Fuel 2007, 86, 758-768. [CrossRef]

35. Pan, Y.; Liao, Y.; Shi, Q.; Hsu, C.S. Acidic and neutral polar NSO compounds in heavily biodegraded oils characterized by negative-ion ESI FT-ICR MS. Energy Fuels 2013, 27, 2960-2973. [CrossRef]

36. Oldenburg, T.B.P.; Jones, M.; Huang, H.; Bennett, B.; Shafiee, N.S.; Head, I.; Larter, S.R. The controls on the composition of biodegraded oils in the deep subsurface-Part 4. Destruction and production of high molecular weight non-hydrocarbon species and destruction of aromatic hydrocarbons during progressive in-reservoir biodegradation. Org. Geochem. 2017, 114, 57-80. [CrossRef]

37. Liu, Y.; Wan, Y.Y.; Zhu, Y.; Fei, C.; Shen, Z.; Ying, Y. Impact of biodegradation on polar compounds in crude oil: Comparative simulation of biodegradation from two aerobic bacteria using ultrahigh-resolution mass spectrometry. Energy Fuels 2020, 34, 5553-5565. [CrossRef]

38. Cheng, X.; Hou, D.; Xu, C.; Wang, F. Biodegradation of tricyclic terpanes in crude oils from the Bohai Bay Basin. Org. Geochem. 2016, 101, 11-21. [CrossRef]

39. Cheng, X.; Hou, D.; Mao, R.; Xu, C. Severe biodegradation of polycyclic aromatic hydrocarbons in reservoired crude oils from the Miaoxi Depression, Bohai Bay Basin. Fuel 2018, 211, 859-867. [CrossRef]

40. Cheng, X.; Hou, D.; Xu, C. The effect of biodegradation on adamantanes in reservoired crude oils from the Bohai Bay Basin, China. Org. Geochem. 2018, 123, 38-43. [CrossRef]

41. Shi, Q.; Hou, D.; Chung, K.H.; Xu, C.; Zhao, S.; Zhang, Y. Characterization of heteroatom compounds in a crude oil and its saturates, aromatics, resins, and asphaltenes (SARA) and non-basic nitrogen fractions analyzed by negative-ion electrospray ionization fourier transform ion cyclotron resonance mass spectrometry. Energy Fuels 2010, 24, 2545-2553.

42. Shi, Q.; Pan, N.; Long, H.; Cui, D.; Guo, X.; Long, Y.; Chung, K.H.; Zhao, S.; Xu, C.; Hsu, C.S. characterization of middletemperature gasification coal tar. part 3: Molecular composition of acidic compounds. Energy Fuels 2013, 27, 108-117. [CrossRef] 
43. Song, H.; Wen, Z.; Bao, J. Influence of biodegradation on carbazole and benzocarbazole distributions in oils from the Bongor Basin, Chad. Org. Geochem. 2016, 100, 18-28. [CrossRef]

44. Liao, Y.; Shi, Q.; Hsu, C.S.; Pan, Y.; Zhang, Y. Distribution of acids and nitrogen-containing compounds in biodegraded oils of the Liaohe Basin by negative ion ESI FT-ICR MS. Org. Geochem. 2012, 47, 51-65. [CrossRef]

45. Liu, W.; Liao, Y.; Pan, Y.; Jiang, B.; Zeng, Q.; Shi, Q.; Hsu, C.S. Use of ESI FT-ICR MS to investigate molecular transformation in simulated aerobic biodegradation of a sulfur-rich crude oil. Org. Geochem. 2018, 123, 17-26. [CrossRef]

46. Harwood, C.S.; Burchhardt, G.; Herrmann, H.; Fuchs, G. Anaerobic metabolism of aromatic compounds via the benzoyl-CoA pathway. FEMS Microbiol. Rev. 1998, 22, 439-458. [CrossRef]

47. Qian, K.; Robbins, W.K.; Hughey, C.A.; Cooper, H.J.; Rodgers, R.P.; Marshall, A.G. Resolution and identification of elemental compositions for more than 3000 crude acids in heavy petroleum by negative-ion microelectrospray high-field fourier transform ion cyclotron resonance mass spectrometry. Energy Fuels 2001, 15, 1505-1511. [CrossRef]

48. Colati, K.A.P.; Dalmaschio, G.P.; de Castro, E.V.R.; Gomes, A.O.; Vaz, B.G.; Romão, W. Monitoring the liquid/liquid extraction of naphthenic acids in brazilian crude oil using electrospray ionization FT-ICR mass spectrometry (ESI FT-ICR MS). Fuel 2013, 108, 647-655. [CrossRef]

49. Mapolelo, M.M.; Rodgers, R.P.; Blakney, G.T.; Yen, A.T.; Asomaning, S.; Marshall, A.G. Characterization of naphthenic acids in crude oils and naphthenates by electrospray ionization FT-ICR mass spectrometry. Int. J. Mass Spectrom. 2011, 300, 149-157. [CrossRef]

50. Cooper, J.E. Fatty acids in recent and ancient sediments and petroleum reservoir waters. Nature 1962, 193, 744-746. [CrossRef]

51. Shimoyama, A.; Johns, W.D. Catalytic conversion of fatty acids to petroleum-like paraffins and their maturation. Nat. Phys. Sci. 1971, 232, 140-144. [CrossRef]

52. Aitken, C.M.; Jones, D.M.; Larter, S.R. Anaerobic hydrocarbon biodegradation in deep subsurface oil reservoirs. Nature 2004, 431, 291-294. [CrossRef]

53. Barth, T.; Høiland, S.; Fotland, P.; Askvik, K.M.; Pedersen, B.S.; Borgund, A.E. Acidic compounds in biodegraded petroleum. Org. Geochem. 2004, 35, 1513-1525. [CrossRef]

54. Bennett, B.; Fustic, M.; Farrimond, P.; Huang, H.; Larter, S.R. 25-Norhopanes: Formation during biodegradation of petroleum in the subsurface. Org. Geochem. 2006, 37, 787-797. [CrossRef]

55. Bennett, B.; Aitken, C.M.; Jones, D.M.; Farrimond, P.; Larter, S.R. The occurrence and significance of 25-norhopanoic acids in petroleum reservoirs. Org. Geochem. 2007, 38, 1977-1985. [CrossRef]

56. Headley, J.V.; McMartin, D.W. A review of the occurrence and fate of naphthenic acids in aquatic environments. J. Environ. Sci. Health Part A 2004, 39, 1989-2010. [CrossRef] [PubMed]

57. Clemente, J.S.; Fedorak, P.M. A review of the occurrence, analyses, toxicity, and biodegradation of naphthenic acids. Chemosphere 2005, 60, 585-600. [CrossRef]

58. Annweiler, E.; Michaelis, W.; Meckenstock, R.U. Identical ring cleavage products during anaerobic degradation of naphthalene, 2-methylnaphthalene, and tetralin indicate a new metabolic pathway. Appl. Environ. Microbiol. 2002, 68, 852-858. [CrossRef]

59. Meckenstock, R.U.; Mouttaki, H. Anaerobic degradation of non-substituted aromatic hydrocarbons. Curr. Opin. Biotech. 2011, 22, 406-414. [CrossRef]

60. Eberlein, C.; Estelmann, S.; Seifert, J.; von Bergen, M.; Mueller, M.; Meckenstock, R.U.; Boll, M. Identification and characterization of 2-naphthoyl-coenzyme A reductase, the prototype of a novel class of dearomatizing reductases. Mol. Microbiol. 2013, 88, 1032-1039. [CrossRef]

61. Lamorde, U.A.; Parnell, J.; Bowden, S.A. Constraining the genetic relationships of 25-norhopanes, hopanoic and 25-norhopanoic acids in onshore Niger Delta oils using a temperature-dependent material balance. Org. Geochem. 2015, 79, 31-43. [CrossRef]

62. Huang, H.; Jin, G.; Lin, C.; Zheng, Y. Origin of an unusual heavy oil from the Baiyinchagan depression, Erlian basin, northern China. Mar. Petrol. Geol. 2003, 20, 1-12. [CrossRef]

63. Sun, P.; Cai, C.; Tang, Y.; Tao, Z.; Zhao, W. A new approach to investigate effects of biodegradation on pyrrolic compounds by using a modified Manco scale. Fuel 2020, 265, 116937. [CrossRef]

64. Tomczyk, N.A.; Winans, R.E.; Shinn, J.H.; Robinson, R.C. On the nature and origin of acidic species in petroleum. 1. detailed acid type distribution in a california crude oil. Energy Fuels 2001, 15, 1498-1504. [CrossRef]

65. Vaz, B.G.; Silva, R.C.; Klitzke, C.F.; Simas, R.C.; Lopes Nascimento, H.D.; Pereira, R.C.L.; Garcia, D.F.; Eberlin, M.N.; Azevedo, D.A. Assessing biodegradation in the llanos orientales crude oils by electrospray ionization ultrahigh resolution and accuracy fourier transform mass spectrometry and chemometric analysis. Energy Fuels 2013, 27, 1277-1284. [CrossRef]

66. Grifoli, M.; Selifonov, S.A.; Chapman, P.J. Transformation of substituted fluorenes and fluorene analogs by Pseudomonas sp. strain F274. Appl. Environ. Microbiol. 1995, 61, 3490-3493. [CrossRef] [PubMed]

67. Sato, S.I.; Nam, J.W.; Kasuga, K.; Nojiri, H.; Yamane, H.; Omori, T. Identification and characterization of genes encoding carbazole 1,9a-dioxygenase in Pseudomonas sp. strain CA10. J. Bacteriol. 1997, 179, 4850.

68. Nojiri, H.; Nam, J.W.; Kosaka, M.; Morii, K.I.; Takemura, T.; Furihata, K.; Yamane, H.; Omori, T. Diverse oxygenations catalyzed by carbazole 1,9a-dioxygenase from Pseudomonas sp strain CA10. J. Bacteriol. 1999, 181, 3105-3113. [CrossRef]

69. Lobastova, T.G.; Sukhodolskaya, G.V.; Nikolayeva, V.M.; Baskunov, B.P.; Turchin, K.F.; Donova, M.V. Hydroxylation of carbazoles by Aspergillus flavus VKM F-1024. FEMS Microbiol. Lett. 2004, 235, 51-56. [CrossRef] 
70. Yamazoe, A.; Yagi, O.; Oyaizu, H. Biotransformation of fluorene, diphenyl ether, dibenzo-p-dioxin and carbazole by Janibacter sp. Biotechnol. Lett. 2004, 26, 479-486.

71. Seo, J.-S.; Keum, Y.-S.; Kyu Cho, I.; Li, Q.X. Degradation of dibenzothiophene and carbazole by Arthrobacter sp. P1-1. Int. Biodeterior. Biodegrad. 2006, 58, 36-43. [CrossRef]

72. Kodama, K.; Umehara, K.; Shimizu, K.; Nakatani, S.; Minoda, Y.; Yamada, K. Identification of Microbial Products from Dibenzothiophene and Its Proposed Oxidation Pathway. Agric. Biol. Chem. 1973, 37, 45-50.

73. Lu, J.; Nakajima-Kambe, T.; Shigeno, T.; Ohbo, A.; Nomura, N.; Nakahara, T. Biodegradation of dibenzothiophene and 4,6dimethyldibenzothiophene by Sphingomonas paucimobilis strain TZS-7. J. Biosci. Bioeng. 1999, 88, 293-299. [CrossRef]

74. van Afferden, M.; Schacht, S.; Klein, J.; Trüper, H.G. Degradation of dibenzothiophene by Brevibacterium sp.DO. Arch. Microbiol. 1990, 153, 324-328. [CrossRef]

75. Gallagher, J.R.; Olson, E.S.; Stanley, D.C. Microbial desulfurization of dibenzothiophene: A sulfur-specific pathway. FEMS Microbiol. Lett. 1993, 107, 31-35. [CrossRef] [PubMed]

76. Gilbert, S.C.; Morton, J.; Buchanan, S.; Oldfield, C.; McRoberts, A. Isolation of a unique benzothiophene-desulphurizing bacterium, Gordona sp. strain 213E (NCIMB 40816), and characterization of the desulphurization pathway. Microbiology 1998, 144, 2545-2553. [CrossRef]

77. El-Gendy, N.S.; Nassar, H.N. Microbial attack of organosulfur compounds. In Biodesulfurization in Petroleum Refining; El-Gendy, N.S., Nassar, H.N., Eds.; John Wiley \& Sons, Inc.: Hoboken, NJ, USA, 2018; pp. 375-458. 